WellBeing International

WBI Studies Repository

1990

\title{
Understanding Dogs through Kinesthetic Empathy, Social Construction, and History
}

Kenneth J. Shapiro

Animals and Society Institute

Follow this and additional works at: https://www.wellbeingintlstudiesrepository.org/acwp_asie

Part of the Animal Experimentation and Research Commons, Animal Studies Commons, and the Other Psychiatry and Psychology Commons

\section{Recommended Citation}

Shapiro, K. J. (1990). Understanding dogs through kinesthetic empathy, social construction, and history. Anthrozoös, 3(3), 184-195.

This material is brought to you for free and open access by WellBeing International. It has been accepted for inclusion by an authorized administrator of the WBI Studies Repository. For more information, please contact wbisr-info@wellbeingintl.org.

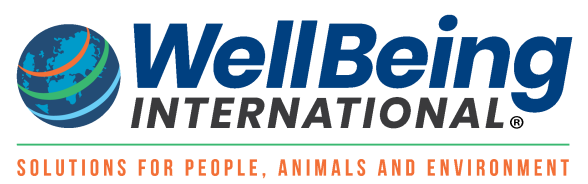


Kenneth J. Shapiro

1990, Anthrozoos, 3, 3, 184-195

\section{Understanding Dogs through Kinesthetic Empathy, Social Construction, and History}

In her recent book Buffalo Gals (198x), Ursula LeGuin presents a collection of stories about our relation to nonhuman animals. Her work demonstrates the advances we have made in the sophistication of our accounts of such matters since Kipling's charming but homocentric and Just So Stories (19xx). LeGuin succeeds in walking a line between a sloppy identification which humanizes and homogenizes animals; and, an alienated and often cruel relation to animals. She at once respects the "space between us," that is the differentness of nonhuman animals from us, and our commonality, in the terms of my thesis here, our common, mutually accessible bodily experiencing. She does this by inviting us to "come into animal presence."

The term, "come into animal presence," she takes from the title of a Denise Levertov poem. The poem, which reads, in part, "What joy when the insouciant armadillo glances at us and doesn't quicken his trotting across the track into the palm bush. What is this joy?" This joy is the possibility of our being in the presence of animals for "(t)he armadillo has some intention to pursue in the palm forest." This joy, to which I invite you here, consists in dwelling in that presence, in inhabiting that intention, that armored but guileless world of the armadillo. I will attempt to show that it is productive to 
do so, while recognizing that our dwelling there as in all other presences, whether human-animal, human-human or human-divine, is necessarily imperfect.

In the less mythopoetic but nonetheless influential literature and practice of our own field we have not typically been interested in the experience of nonhuman animals. In fact, at least apparently, psychology got along for over a generation without interest even in human experience. Recently, there have been a number of calls to inaugurate (Nagel, Griffin, Burghardt), or really, reinaugurate (Grene) such a focus. But why should we be interested in an animal's presence or experiencing? In his paper on animal awareness (198x), Burghardt states:

Let us retain an open-minded delight in animal abilities, a respect for what they may be experiencing, and a balance between skepticism and incredulity. And we must not forget, nor ignore, the use, or misuse, to which our findings will be put in the growing debate on the treatment of our fellow creatures. (His emphasis).

There are three reasons there--delight or joy, respect, and impact on their welfare.

of course, it is not only what we understand of animals, whether of their abilities or experiencing, that effects them; it is how we arrive at that understanding -- our method. This paper describes a method in the form of a set of investigatory postures for the study of animals. 
Following the suggestion of Ricoeur that we (and I would include nonhuman animals) are both subjects and objects, ( ), the method is necessarily a mixed one. ( ). It has three moves. The primary posture is one of kinesthetic empathy through which the investigator attempts to directly sense the motor intention or attitude or project of the animal. This emphasis on the investigator's bodily sensibility is an extension of an earlier effort of my own, which described a method based on bodily reflective modes. The empathic move is informed in two ways which, then, constitute the mixed methodology. The investigator reads relevant texts in both popular and scientific literature to arrive at an interpretation of the social construction of the animal under investigation. The reading must assess the presence of the social construction in the investigator's preconceptions and on the likely impact of the social construction on the actual experience of the animal. Secondly, the investigator must become a historian of the individual animal or animals under study. In effect, he or she develops a biographical account. This also informs the attempts at kinesthetic empathy.

I present the method here through its application to the study of an individual dog. (The paper is long so I have opted to summarize the methodological discussion in the paper through a handout. )

To facilitate our coming into an animal's presence, I have brought my pet dog Sabaka with me here today. "Sabaka, come" (firm). "Sabaka, come!" (insistent). 
Sabaka (the name comes from the Russian for dog) is a five year old male dog, of mixed breed. He has been in our household since he was about four weeks old, at which time we got him at a local animal shelter. He had been abandoned at a town dump. Three months or so after he joined us, we obtained a second dog, a female collie mix, probably four years old, also from a shelter. We had decided on two dogs so that they would be company for each other. Undoubtedly influenced by the local Maine practice of keeping a dog outside even in winter, as a watchdog, we planned to raise these dogs primarily in an outdoor yard with a run joining a shed in the barn. Elkie, the collie, adopted Sabaka and the two were inseparable for about a year, when Elkie died from an illness contracted before we acquired her. That event changed our relation to Sabaka significantly, as I will describe. A second major event in Sabaka's life, in his third year, was our absence from the house for a six month period, during which time Sabaka was left with a housesitter. With this background sketch, the remainder of the presentation here will be in the form of three vignettes describing Sabaka's behavior and reflections on that behavior. In phenomenological terms, the description will move from concrete accounts of a particular dog's world to some of the structures of that umwelt.

1. In the interests of time, I will only summarize the first vignette sa the example is familiar to most pet owners and the reflections are in directions with which most of this audience is probably sympathetic. In it, I describe some of 
Sabaka's play with me -- a game of chase and keep away which although apparently simple, really is quite intricate in the feints, out - of - bounds, timeouts, and particularly, in the complex repertoire of interactions between us -- if he moves under the chair which is too low for me to follow and I go around to the left, then his move is such and such.

In reflection, I note that in the course of the game the way I typically know his moves, and more generally what is significant to him, is direct and immediate. I liken my posture to the way a tennis player anticipates the next shot of his or her opponent. It is an empathic posture in which I sense the bodily attitude, stance, and incipient moves of the other. This kinesthectic empathy is a possible investigatory posture.

Through it, I sense that Sabaka is concernfully absorbed in a lived space consisting of furniture and, as well, mobile bodies which he knows as particular invitations to his moves. For example, my only incipient moves are meaningful to him with respect to a complex field of barriers and accesses and with respect to his own possible moves.

His experience is thoughtful in these terms. His is a prelinguistic, nonreflective, sensori-motor judgment -- an intelligence consisting of know-how, again, of possible moves.

The important role of movement in the constitution of his or her world by a dog would seem to have some ethical implications for research in which a dog is restrained in a body hammock, as for example, in the learned helplessness paradigm. 
2. When he is outside Sabaka spends much of his time lying in a certain spot, at the head of the drive. This place allows him an optimal view both down the driveway to the street and through the windows of the kitchen. It also allows him to be in the sun. From this spot, he can comfortably half-sleep while vigilantly smelling, listening and watching, ready to bark, bay and half-charge at passers-by. He also can watch family comings and goings. Other places within the house offer some of these features -- under the couch in the playroom, on the second floor landing, at the threshold between the dining room and the kitchen.

Currently, Sabaka sleeps overnight on the landing, although I had originally intended for him to sleep outside. When Elkie's premature death derailed that plan, slowly Sabaka moved to sleeping arrangements closer to us in a shed attached to the main house. However, during our six month stay abroad, we instructed the housesitter to let him sleep inside as she was away during the day, during which time he was outside, it was very cold at night, and we felt guilty at our absence from him. Also, in retrospect, it is clear that there was a conflicting construction of "pet" at work here vying with the Maine woodsman construction of outdoor watchdog -- namely, that of dog as an integral member of the family. Apparently it took family absence to give that construction formative power. In any case, Sabaka now sleeps on the landing twelve feet from my bedroom.

During the day and early evening when in the house, he stays under the couch sometimes to be away from us as when he 
has something he should not have, and sometimes to be near as when I am on the couch. When we eat in the dining room, he remains on the threshold of that room, although over the years almost imperceptibly that threshold has gotten closer and closer to my soup, as the sleeping arrangement has gotten closer to my bed. At most any time day or night he may, if given the chance, sleep on a second favored couch in my study. It would seem that I can not train him otherwise. While he generally takes a somewhat distant position of surveillance with respect to us, he will quickly occupy a bedspread or cushion left on the floor and when curled up next to one of us will immediately commandeer the apparent choice center of another family member's resting spot even as he or she is setting it up or rolling over for a second to change the channel.

Some reflections on these actions: Apparently, Sabaka lives space in various ways. Some of these have been described in ethological literature on dogs, and on their evolutionary ancestors, wolves. With respect to the instinctive behavioral patterns of the latter both Scott and Fuller ( ) and Fox ( ) assert dogs retain much in common. Most of the activities I have just described fit between a dog's territorial space, that space which is defended, marked, and tracked and, on the other hand, the "personal space" (Katz, p. 95) at the border of which and within which a dog performs numerous complex greeting, courting, dominance determination and care soliciting behaviors. Between, then, roughly territorial and personal space is what I will refer to as the space of place. 
Within the literature on Canidae instinctive patterns are described under the rubric of lair behavior--shelter and care seeking, building and maintenance behaviors (Scott and Fuller, pp. 64-65). Informed by these descriptions and their, typically, functional that is evolutionary explanatory accounts, this investigator then returns to the animal under study and attempts to empathize kinesthetically with his or her lived sense of these activities. What is Sabaka's bodily experience of the space of place?

So I want to appreciate directly Sabaka's bodily experience, his posture, attitude, incipient and actual moves and be carried along toward them as features of his own intended world. As I watch him in this way, I sense that he spends much time seeking and checking on previously established places. As he approaches a prospective place his bodily posture already begins to assume the contour and, as well, appreciate the lookout that the prospective place would offer. He begins to circle it and to curl and lower his body. There is more to understanding this than as the vestigial instinctive grass flattening or snake checking behavior of his wolf ancestors. In his bodily attitude I am aware of his sense of how this space could contain him. He is, as it were, trying it on for size. He is seeking a kind of space which he already knows bodily. It is an optimal resting place that provides a sense of the protection and lookout advantage given by a partial enclosure. It also allows comfort, the warmth of the sun, or the softness of the carpet. As a vantage point it is both a lookout or rather 
smelling station or listening post for detecting outside threat and for keeping track of our presence. At the same time, it is a place that gives him a sense of being with or close to us; in it he is in the family lair. Once in that space of place he lives it in a certain bodily way. He curls his body in the recess for physical warmth and for closeness to the pack or family of which he is a member; he sighs and purrs at this contentment and security much like he does when petted; while he lies oriented to keep watch for both strangers and for the possibility of even more access to the family hearth. But, again, he already assumes this posture as a kind of set, as the project of finding such places. The bodily posture of place seeking and place sought are correlative, and by kinesthetically empathizing with his body I can direct myself from it to the intended place, the way of being and point of view it, in turn, intends. More generally, I sense that Sabaka's bodily experience intends objects in the world as possible sites of his inhabitation. He is looking for secure places. He inhabits the space of place in the several senses that he tries them out by virtually dwelling in them and in that once established they are his habitations, that is places he has and holds--etymologically from habeo, to have and hold [Jager, p. 156].

Adding to our description of Sabaka in the first vignette, the structure of his bodily experience consists of possible habitations, as well as possible moves. In addition to the bodily attitude which intends objects as to-be-effected, he assumes a bodily attitude which intends complex configured 
objects as to-be-lived-in and lived-from, as optimal vantage points, as advantages. One way Sabaka lives space is as to be appropriated, as to be made his own, as to be incorporated so that it serves as and becomes his point of view. The historical account of the journey of his primary sleeping place moving closer and closer to the family lair shows that this appropriation of place can be an on-going project. Sabaka slowly, over a long period of time, whittled away at the boundaries of permissible sites. This project of seeking, establishing, and maintaining secure places is reminiscent of Jager's description of a human architectural project. As Jager describes, architecture is a codification of a certain way of dwelling, in my terms here, of kinds of appropriated space. A space as place is an invitation to live one's body in a certain way. Sabaka's appropriated space is an architectonic space, remaining uncodified and known to him only as a preferred place. While the emphasis on spatiality here admittedly may reflect the peculiar construction of pets in the Western world and/or the investigatory posture being promoted, speculatively, I would suggest that spatiality may ground the being of Sabaka in the way that it is often claimed, particularly following Heidegger, that temporality grounds human being. This is not to say that there are not temporal structures operative in his experience. However and more particularly, I would suggest that place primarily grounds being for Sabaka. He belongs in the place and relates to others from and through that place. He can just lie there for hours because he is not primarily waiting, he 
is not primarily anticipating, he is not thinking in our sense; he is already arrived, he is at home.

Correlatively, his is a spatial identity. In contrast to a reflective self that is constituted and developed as a unity through and over time, his is a self constituted through association with a space. Sabaka's habitat is his self. The space he has and holds is his appropriated self. He is radically, ontologically place- dependent. His being is not a being in question; it is not continually thrown forward and resynthesized in and through temporal ekstases.

This peculiar ontological dependence on space is a vulnerability which has ethical implications for the practice of housing animals in cages in laboratory research.

3. I begin this third vignette/reflection with a set of apparently disconnected examples. When Sabaka has been given a special treat or has brought one in from outside-- a bone or the like, and Zeke, the neighbor's dog, visits, Sabaka will growl at him even if the bone is nowhere in sight and has been left unattended for hours. Then he will maintain a position between the other dog and the bone, by aggressively snarling if necessary. However, more commonly, Zeke's arrival signals the beginning of play as an old sock long gathering dust suddenly becomes, once again, the vehicle for an extended tug-of-war. While I eat breakfast Sabaka lies, not on the threshold of the dining room, but out in the hall leading to my study. Following breakfast, as I pass through the hallway, he gets up and heads toward the study, turning frequently to establish 
whether I am following him. I usually do so, opening the far door of the study to let him up the stairs to a favored sunroom. on a walk recently, Sabaka went off sniffing, nose to ground, tail wagging high in the air. I continued my walk and, although calling for him from time to time, did not see him again until I returned to the house. This was an unusual occurrence and Sabaka looked at me a bit sheepishly. I was mean enough to confirm his concern by barking at him sharply and withholding his usual post-walk cookie. I went about my business, only returning a half hour later to the play room where he was lying. I did not greet him and he looked at me continuously but without moving. I relented finally, saying, "Okay, Sabaka; it's okay." He immediately approached, solicited me to kneel, stood up on his hind quarters and licked my chin. Then, he went about his business, trying to find a warm spot in the sun. Sabaka will seek affection or solicit care as a complex function of anumber of conditions such as the amount of time we have been apart or, as in the incident just related, his sense of my feelings toward him. He also stays closer and begins to be a bit oversolicitous of affection when the rest of the family is away. Also, when he thinks I am hurt or when I act in a way not familiar to him, in addition to staying closer and watching me more, he will approach and sniff at me, preferably at my face. In a sense, these three admittedly selective examples suggest a functionalist or behaviorist way of thinking about relationships. It is as if Sabaka's action in relationship to others is adequately intelligible in terms of contingencies of 
reinforcements or some "what's in it for me" pay-off matrix. Zeke's visit is merely a threat to Sabaka's prize bone, or at best, an occasion for play; or my anticipated entry into the hallway is a vehicle for access to a comfortable place.

These modes of understanding can be applied as well to the third set of examples. Here, while food and physical comfort are, at least less directly at stake, the interactions between Sabaka and me could be reduced to learned security operations or even further reduced to an early bonding maintained largely through instinctive patterns of behavior. Certainly the facelicking itself has a clear instinctive component--as a pup licks the face of mother returning to the den. While taking these explanations and, as well, other less scientific but also pervasive social constructions into account, the present method results in a different sort of discourse and purports to raise and attempt to answer other questions. For examples, in what sense may Sabaka be said to seek and maintain relationships whether with a conspecific or with a human? Is the term "relationship" applicable and appropriate in its full meaning? If so, what is Sabaka's experience of a relationship? What is Sabaka's experience of me? How am I present to him?

In these moments involving Sabaka and me when I have reprimanded him, or I am upset, or when the rest of the family is away Sabaka is clearly riveted on me. I directly sense his searching for my bodily attitude to him. He is, as it were, studying my kinesthetics--my posture, bearing, incipient movements and the like. Without getting unnecessarily into 
Laingian knots, through kinesthetic empathy I sense that his experience is to sense my bodily experience. For his part, this is a habitual way in which he knows me. He also rivets on me when it is near his dinnertime or when I am beginning to mobilize to take him for a walk. However, what he is checking on here is different, and is perhaps more indicative of what might be termed a relationship concern. He is checking to see if it is all right between us or with us. When I say "it's okay Sabaka", sometimes he will simply walk away without approaching to face-lick. But he walks away differently than when he approached or was riveted on me. His posture is no longer sheepish, or intimidated, or tight or tentative. He walks away secure. Secure in what: Am I simply another instance for him of a secure place, although a more mobile one? Is relationship for him reducible to place, so that his experience of checking on me has the same structure as checking to see if the landing is available? or, is this posture not reducible to that related to place, but of a different, perhaps more originary, structure? As it is for many of us, is, for Sabaks, the primary relationship "being okay" such that without that, he cannot play, or go for a walk, or even seek security of place in anything like the same way?

After sensing that it is "okay, Sabaka", does he walk away with a different sense of me, of Sabaka, of us, or of some generalized atmosphere? Is he in relationship; is he carrying "us" with him if not as image then as a different bodily sense of it being okay with us? Is, then, the converse the case--that 
place is reducible to, or is a substitute for, or predicated on our relationship being okay? of course, Sabaka does not predicate or register or refer or depict or represent. He, rather, always is concernfully absorbed. The question we are raising here is whether that concernful absorption can contain a sense of a relationship. My empathetic sense of Sabaka begins to suggest it might--that Sabaka carries with him a sense of how it is between us.

To conclude, invitations to move and bodily sensibility are the basis of meaning in Sabaka's experience. For him, meaning does not occur in or consist of a semantic field of, say, differences, similarities, and associations. Rather, meaning occurs in and is the contexts of possible moves; of possible ways of living and maintaining space; and, as the last reflection suggests, of forms of relationship with others. For Sabaka, meaning consists of and is known through bodily experience. To understand the complex, intimate, and wonderful choreographies of that world, it is helpful for an investigator to assume a posture of bodily sensitivity to it--to kinesthetically empathize with Sabaka. 